\title{
ĐÁNH GIÁ KẾT QUẢ ĐIỀU TRI UNG THƯ PHỔI KHÔNG TẾ BÀO NHỎ DI CĂN NÃO CÓ ĐộT BIẾN EGFR BẰNG THUỐC ỨC CHẾ TYROSINE KINASE KẾT HỢP XẠ PHẪU DAO GAMMA QUAY TẠI BỆNH VIỆN BACH MAI
}

\author{
Nguyễn Văn Kiên ${ }^{1}$, Phạm Cẩm Phương², \\ Nguyễn Thị Phương Thảo ${ }^{3}$
}

\section{TÓM TẮT}

Muc tiêu: Đánh giá hiêu quả và độc tính của phác đồ kết hợp thuốc ức chế tyrosine kinase và xạ phẫu dao gamma quay điều trị ung thư phổi không tế bào nhỏ di căn não có đột biến EGFR tại Trung tâm $Y$ học hạt nhân và Ung bướu Bệnh viện Bạch Mai. Đối tượng và phương pháp nghiên cứu: Nghiên cứu hồi cứu kết hợp tiến cứu trên 53 bệnh nhân được chẩn đoán ung thư phổi không tế bào nhỏ có đột biến gen EGFR, được điều trị bằng thuốc ức chế tyrosine kinase (TKI) kết hợp xạ phẫu dao gamma quay tại Trung tâm Y học hạt nhân và Ung bướu Bệnh viện Bạch Mai từ 01/2016 đến 12/2020. Kết quả: 50,9\% nam, tỷ lệ nam/nữ: 1,04/1, chủ yếu ở độ tuổi 50-69 (73,6\%). Thể trạng theo ECOG từ $0-2$, chủ yếu là $0-1(81,1 \%)$. Di căn não thường kết hợp di căn các cơ quan khác $(64,2 \%)$, nhiêu nhất là di căn xương $(49,1 \%)$, di căn phổi, màng phổi $(28,3 \%)$. Các thuốc TKI được sử dung: Erlotinib (47,2\%), Gefitinib (43,4\%), Afatinib (9,4\%). Triệu chứng cơ năng cải thiện ở $88,7 \%$ bệnh nhân. Tỷ lệ đáp ứng khách quan đạt $69,0 \%$, chủ yếu là đáp ứng một phần $(66,7 \%)$, không có sự khác biệt có ý nghĩa thống kê giữa các thuốc TKI với $p>0,05$. Thời gian sống thêm được tính theo phương pháp Kaplan-Meyer. Thời gian sống thêm bệnh không tiến triển đạt trung vị 14,0 tháng (khoảng tin cậy 95\%: 11,6-16,4 tháng). Đáp ứng khách quan sau 3 tháng là yếu tố tiên lượng thời gian sống thêm bệnh không tiến triển với $p<0,01$. Trung vị thời gian sống thêm bệnh không tiến triển tại não đạt 22,0 tháng (khoảng tin cậy $95 \%$ : 18,2-25,8 tháng). Điêuu trị toàn thân bằng Erlotinib cho thời gian sống thêm bệnh không tiến triển tại não dài hơn Gefitinib và Afatinib khi phân tích đa biến với $p<0,05$. Trung vị thời gian sống thêm toàn bộ đạt 25,0 tháng (khoảng tin cậy 95\%: 11,039,0 tháng), tỷ lệ sống 1 năm đạt $85,7 \%, 2$ năm đạt $52,0 \%$. Phân tích đa biến, điều trị toàn thân bước 2 bằng thuốc TKI bước 2 cho trung vị thời gian sống thêm toàn bộ dài hơn hóa chất và không điều trị lần lượt là 39 tháng, 20 tháng, 14 tháng, sự khác biệt có ý nghĩa thống kề với $p<0,05$. Tác dụng phụ hay gặp của phác đồ là ban da $(52,8 \%)$, tiêu chảy $(16,9 \%)$, tăng men gan $(11,3 \%)$, đều mức độ nhe đến vừa. Không có biến chứng giãn não thất, hoại tử mô não

${ }^{1}$ Bệnh viện quân y 110

${ }^{2}$ Trung tâm Y học hạt nhân và Ung bướu, Bệnh viện Bach Mai

${ }^{3}$ Viện ung thư, Bệnh viện Trung ương quân đội 108

Chịu trách nhiệm chính: Nguyển Văn Kiên

Email: Dr.Kien39A@gmail.com

Ngày nhận bài: 22.6.2021

Ngày phản biên khoa họ: 19.8.2021

Ngày duyệt bài: 26.8.2021

lành sau xạ phẫu. Tiêu chảy gặp nhiều ở nhóm điều trị bằng Afatinib hơn Erlotinib và Gefitinib, sự khác biệt có ý nghĩa thống kê với $\mathrm{p}<0,05$. Đa số bệnh nhẩn tuân thủ phác đồ, độc tính mức độ vừa làm 2 bệnh nhân phải tạm dừng thời gian ngắn, 2 bệnh nhân giảm liêu. Kết luận: Điều trị bệnh nhấn ung thư phổi di căn não có đột biến EGFR bằng thuốc ức chế tyrosine kinase kết hợp xạ phẫu dao gamma quay là phương pháp hiệu quả và an toàn.

Ti̛ khóa: thuốc ức chế tyrosine kinase, xa phẫu bằng dao gamma quay, ung thư phổi di căn nã̉o, đột biến EGFR.

\section{SUMMARY}

EVALUATING THE RESULTS OF TREATMENT EPIDERMAL GROWTH FACTOR RECEPTOR MUTANT NON-SMALL CELL LUNG CANCER METASTASIS BRAIN WITH TYROSINE KINASE INHIBITORS COMBINED WITH ROTATING GAMMA SYSTEM AT BACH MAI HOSPITAL

Object: Evaluating the efficacy and toxicity of treatment epidermal growth factor receptor mutant non small cell lung cancer metastasis brain with tyrosine kinase inhibitors combined with Rotating gamma System at the Nuclear Medicine and Oncology Center, Bach Mai Hospital. Patient and Methods: A retrospective combined prospective study on 53 patients diagnosed with epidermal growth factor receptor mutant non small cell lung cancer metastasis brain, treated with tyrosine kinase inhibitors combined with Rotating gamma System at the Nuclear Medicine and Oncology Center, Bach Mai Hospital. Results: $50.9 \%$ men, the male/female ratio is equal (1.04/1), mainly in the age group 50-69 (73.6\%). PS ECOG from 0 to 2 , mainly $0-1(81.1 \%)$. Brain metastasis often combine with metastasis to other organs $(64.2 \%)$, most of which was bone metastasis $(49.1 \%)$, followed by metastases in lung, pleura (28.3\%). The TKIs contained: Erlotinib (47.2\%), Gefitinib (43.4\%), Afatinib (9.4\%). The rate of patients improved functional symptoms in $88.7 \%$. The objective response rate was $69.0 \%$, mainly partial response $(66.7 \%)$, there was no statistically significant difference between the TKIs with $p>0.05$. Survival time was calculated according to the Kaplan-Meyer method. The median progression-free survival (PFS) time was 14.0 months (95\% CI: $11.6-16.4$ months). Objective response was a predictor of PFS longer with $\mathrm{p}<0.01$. The median intracranial PFS time was 22.0 months (95\% CI: 18.2-25.8 months). Systemic treatment with Erlotinib resulted in a longer duration of intracranial PFS time than Gefitinib and Afatinib in multivariate analysis with $p<0.05$. The median 
overall survival (OS) time was 25.0 months (95\% CI: 11.0-39.0 months), the 1-year survival rate was $85.7 \%$, and the 2-year survival rate was $52.0 \%$. Multivariate analysis, second-line systemic treatment with tyrosine kinase drugs (Afatinib, osimertinib) for median overall survival time was longer than chemotherapy and no treatment was 39 months, 20 months, 14 months, respectively, the difference was statistically significant with $\mathrm{p}<0.05$. Common side effects of the regimen were skin rash $(52.8 \%)$, diarrhea (16.9\%), increased liver enzymes (11.3\%), all mild. to medium. There were no complications of ventricular dilatation, necrosis of brain tissue after radiosurgery. Diarrhea was more common in the Afatinib group than Erlotinib and Gefitinib, the difference was statistically significant with $p<0.05$. The majority of patients adhered to the regimen, moderate toxicity caused 2 patients to stop for a short time, 2 patients to reduce the dose. Conclusion: Treatment of patients with brain metastatic lung cancer with EGFR mutations with tyrosine kinase inhibitors combined with rotary gamma knife radiosurgery is an effective and safe method.

Keywords: tyrosine kinase inhibitors, rotating gamma knife, brain metastatic lung cancer, EGFR mutation

\section{I. ĐĂT VẤN ĐỀ}

Ung thư phổi là bênh lý ác tính có tỷ lệ mắc và tử vong cao nhất toàn cầu hiện nay. Theo GLOBOCAN 2020, tỷ lệ mới mắc và tỷ lệ tử vong của ung thư phổi trên thế giới lần lượt là $11,4 \%$ và $18,0 \%$ [1]. Di căn não nguồn gốc từ ung thư phổi cũng chiếm tỷ lệ cao nhất và là nguyên nhân chính dẫn đến tử vong ở nhóm bệnh nhân (BN) này. Một nghiên cứu gần đây tại Hoa Kỳ cho thây $22 \%$ BN ung thư phổi bị di căn não ở thời điểm chẩn đoán ban đâu và di căn não sẽ xuất hiện ở khoảng $40 \%$ BN trong quá trình phát triển của bệnh [2]. Từ khi xạ trị được ứng dụng vào điều trị u não những nắm 1950 xạ trị toàn não và về sau có xạ phẩu là giải pháp chủ yếu kiểm soát u não. Trong đó, xạ phẫu hiệu quả cao ở các trường hợp di căn não số lượng hạn chế, được chỉ định cho các trường hợp u di căn não $<4$ u, kích thước u não $<5 \mathrm{~cm}$, các trường hợp di căn não đa ổ thì xạ trị toàn não lại được chỉ định nhờ khả năng kiểm soát u di căn não tốt hơn [3]. Những năm đầu thế kỷ 21 , người ta đã biết đến nhiều loại đột biến gen thúc đẩy quá trình tăng sinh của tế bào ung thư phổi như EGFR, ALK, RET, MET, ROS 1, BRAF... Những phát hiên này đã mở ra một liệu pháp điều trị mới là điều trị nhắm trúng đích. Ban đầu là sự ra đời các thuốc ức chế tyrosin kinase (TKI) của EGFR, những thuốc này cho tỷ lệ đáp ứng cao lên đên khoảng $70 \%$, vượt trội so với hóa chất (khoảng $28-30 \%$ với hóa chất bộ đôi) [4]. Đặc biệt, những thuốc này có thể kiểm soát được $u$ di căn não, tỷ lệ đáp ứng u nội sọ gần tương đương với ngoại sọ, mở ra một liệu pháp mới trong điều trị tổn thương di căn não. Phác đồ kết hợp thuốc TKI với xạ phẫu đã được áp dung trong điều tri nhóm $\mathrm{BN}$ ung thư phổi không tế bào nhỏ (UTPKTBN) di căn não ở nhiều trung tâm ung bướu lớn trên thế giới. Tuy nhiên, hiêu quả và các yếu tố ảnh hưởng đến kết quả của sự kết hợp giữa thuốc TKI và xạ phầu đối với $B N$ UTPKTBN di căn não còn nhiều vấn đề chưa rõ ràng, kết quả của một số nghiên cứu còn có nhiều khác biêtt. Ở Việt Nam, thuốc TKI kết hợp xạ phẫu được áp dụng tại một số Bệnh viện tuy nhiên chưa có nghiên cứu báo cáo về kết quả điều trị. Vì vây, chúng tôi thực hiện đề tài này nhằm muc tiều: Đánh giá hiểu quả và độc tính của phác đồ kết hợp thuốc ức chế tyrosine kinase và xa phẫu dao gamma quay điều trị ung thư phổi không tế bào nhỏ di căn não có đồt biến gen EGFR tại Bệnh viện Bạch Mai.

\section{II. ĐỐI TƯỢNG VÀ PHƯƠNG PHÁP NGHIÊN CỨU}

- Đối tượng nghiên cứu: $53 \mathrm{BN}$ được chẩn đoán UTPKTBN có đột biến gen EGFR, được điều trị bằng thuốc ức chế tyrosine kinase kết hợp xạ phẫu dao gamma quay tại Trung tâm $Y$ học hạt nhân và Ung bướu Bệnh viện Bạch Mai thời gian từ 01/2016 đến 12/2020.

- Tiêu chuẩn lựa chọn là BN có chẩn đoán mô bệnh học là ung thư biểu mô tuyến, có đột biến EGFR nhạy thuốc TKI thế hệ 1,2. U di căn não số lượng từ $1-3 \mathrm{u}$, kích thước $\mathrm{u}<5 \mathrm{~cm}$. Không có tiền sử điêuu trị ung thư phổi trước đó bằng hóa chất, phẫu thuật, xạ trị, không mắc các bệnh lý thần kinh như rối loạn tâm thần, thiểu năng trí tuệ, động kinh.

- Thiết kế nghiên cứu: Hồi cứu kết hợp tiến cứu.

- Phương pháp thu thập số liệu: Thu thập thông tin từ hồ sơ bệnh án, kết hợp phỏng vấn bệnh nhân, người nhà. Xử lý và phẩn tích số liệu bằng phần mềm SPSS 20.0.

- Đạo đức nghiên cứu: Thông tin của đối tượng nghiên cứu được đảm bảo giữ bí mật và chỉ dùng cho muc đích nghiên cứu.

- Thiết bị: Hệ thống dao Gamma quay ART$6000^{\mathrm{TM}}$, thuốc TKI thế hệ 1: Gefitinib (Iressa $250 \mathrm{mg}$ ), Erlotinib (Tarceva 150mg), thế hệ 2: Afatinib (Giotrif 30mg, 40mg).

- Quy trình điều trị: BN thỏa mãn tiêu chuẩn lựa chọn được chỉ định điều trị toàn thân bằng thuốc TKI, hội chẩn xác định kế hoạch xạ phẫu. Sau xa phẫu điều trị chống phù não, duy trì thuốc TKI, định kỳ đánh giá đáp ứng, theo 
dõi tiến triển, tử vong. Các thông tin trong quá trình điều trị được ghi nhận qua hồ sơ bệnh án và phỏng vấn bệnh nhân, người nhà.

\section{KẾT QUẢ NGHIÊN CỨU}

\section{Một số đặc điểm nhóm bệnh nhân} nghiên cứu

\begin{tabular}{|c|c|c|c|}
\hline \multicolumn{2}{|c|}{ Đặc điểm } & $\begin{array}{c}\text { Số } \\
\text { lượng }\end{array}$ & $\begin{array}{c}\text { Tỷ lệ } \\
\mathbf{\%}\end{array}$ \\
\hline \multirow{2}{*}{ Giới tính } & Nam & 27 & 50,9 \\
\cline { 2 - 4 } & Nữ & 26 & 49,1 \\
\hline \multirow{3}{*}{ Nhóm tuổi i } & $<50$ tuô̂i & 5 & 9,4 \\
\cline { 2 - 4 } & $50-69$ tuô̂i & 39 & $\mathbf{7 3 , 6}$ \\
\cline { 2 - 4 } & $\geq 70$ tuô̂i & 9 & 17,0 \\
\hline \multirow{2}{*}{ PS ECOG } & $0-1$ & 43 & $\mathbf{8 1 , 1}$ \\
\cline { 2 - 4 } & 2 & 10 & 18,9 \\
\hline
\end{tabular}

" Cải thiện $(n=47)$ " Ổn định $(n=4)$ " Xấu đi $(n=2)$ "

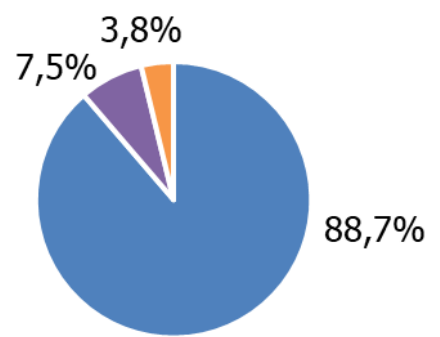

\section{Biểu đồ 1. Tỷ lệ đáp ứng chủ quan sau 2 tháng điêu trị}

\begin{tabular}{|l|c|c|c|}
\hline \multirow{2}{*}{$\begin{array}{c}\text { Số cơ quan } \\
\text { di căn khác }\end{array}$} & 1 & 19 & 35,8 \\
\hline \multirow{3}{*}{ Vị trí di căn } & $2-4$ & $\mathbf{3 4}$ & $\mathbf{6 4 , 2}$ \\
\cline { 2 - 4 } & Xương & $\mathbf{2 6}$ & $\mathbf{4 9 , 1}$ \\
\cline { 2 - 4 } & Phố, màng phối & 15 & 28,3 \\
\hline \multirow{3}{*}{ Thuốc đích } & Khác & 8 & 15,1 \\
\cline { 2 - 4 } & Erlotinib & $\mathbf{2 5}$ & $\mathbf{4 7 , 2}$ \\
\cline { 2 - 4 } & Gefitinib & $\mathbf{2 3}$ & $\mathbf{4 3 , 4}$ \\
\cline { 2 - 4 } & Afatinib & 5 & 9,4 \\
\hline
\end{tabular}

Nhận xét: Nhóm tuối từ 50-69 chiếm tỷ lệ nhiều nhất $(73,6 \%)$, tỷ lệ nam/nữ ngang nhau $(1,04 / 1)$. PS ECOG chủ yếu là $0-1(81,1 \%)$. Di căn não thường kết hợp di căn các cơ quan khác $(64,2 \%)$, nhiêu nhất là di căn xương $(49,1 \%)$, di căn phổi, màng phổi (28,3\%). Các BN được điều trị toàn thân chủ yếu bằng Erlotinib $(47,2 \%)$, Gefitinib (43,4\%), tỷ lệ ngang nhau.

$$
\begin{array}{ll}
\text { - Hoàn toàn }(\mathrm{n}=1) & \text { - Một phần }(\mathrm{n}=28) \\
\text { - Ô̂n định }(\mathrm{n}=11) & \text { - Tiến triển }(\mathrm{n}=2)
\end{array}
$$

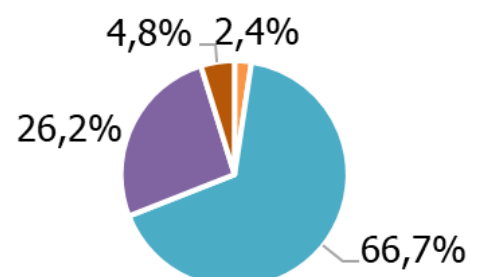

Biểu đồ 2. Tỷ lệ đáp ứng khách quan sau đîêu trị $>\mathbf{3}$ tháng

Nhân xét: Đánh giá chung, đa số BN đều có cải thiện triệu chứng $(88,7 \%)$, đáp ứng cao nhất là đau đầu, yếu liệt, đau ngực, ho $(>85 \%)$, thấp nhất là đau xướng $(73,7 \%)$. Tỷ lệ đáp ứng khách quan đạt 69,0\%. Tỷ lệ kiểm soát bệnh sau >3 tháng đạt 95,2\%.

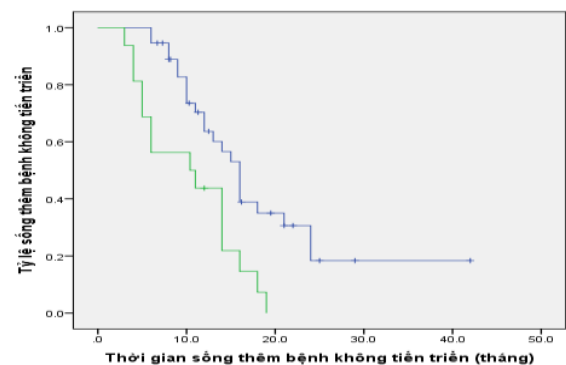

Trung vị STBKTT: 14,0 (khoảng tin cậy 95\%: 11,6-16,4); Đáp ứng: 16,0 (14,1-17,9); Không đáp ứng: 10,4 (0,6-20,2) HR: 0,39(0,20-0,76); Log-Rank $P=0,005$

\section{Biểu đồ 2. Liên quan thời gian sống thêm} bênh không tiến triển theo đáp ứng

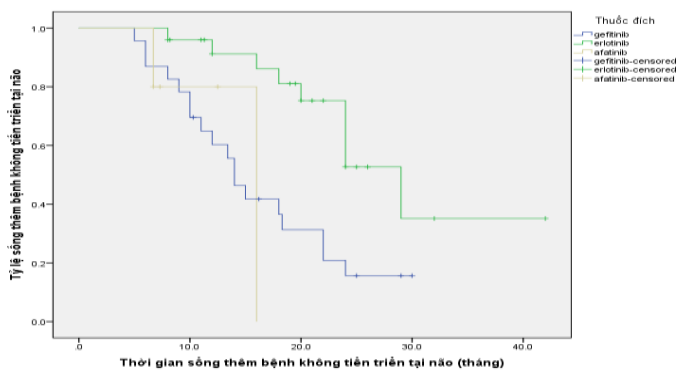

Erlotinib Afatinib Gefitinib Trung vi STBKTT tại não: 22,0 (khoảng tin câyy 95\%: 18,2-25,8); Erlotinib Gefitinib: $p=0,01$ Erlotinib - Afatinib: $p=0,02$; Gefitinib - Afatinib: $p=0,63$

Biểu đồ 4. Liên quan thời gian sống thêm bệnh không tiến triển tại não theo thuốc TKI Nhận xét: Điều trị toàn thân bằng Erlotinib là yếu tố tiên lượng độc lập ảnh hưởng đến thời gian sống thêm bệnh không tiến triển tại não khi phân tích đa biến (với $p<0,05$ )

Bảng 2. Đáp ứng khách quan theo kích thước u phổi, u não, chỉ điểm u sau 3 tháng

\begin{tabular}{|c|c|c|c|c|c|c|}
\hline \multicolumn{2}{|c|}{ Yếu tố } & Trung bình & Min & Max & Số lượng & p \\
\hline $\begin{array}{c}\text { Kích thước u } \\
\text { phổi }(\mathrm{mm})\end{array}$ & Ban đầu & $41,3 \pm 11,7$ & 22,0 & 65,0 & 42 & $<0,001$ \\
\cline { 2 - 6 } & Sau 3 tháng & $30,0 \pm 15,6$ & 0 & 72 & & \\
\hline
\end{tabular}


VIETNAM MEDICAL JOURNAL N02 - SEPTEMBER - 2021

\begin{tabular}{|c|c|c|c|c|c|c|}
\hline \multirow{2}{*}{$\begin{array}{l}\text { Kích thước u } \\
\text { não (mm) }\end{array}$} & Ban đầu & $17,1 \pm 7,7$ & 5,0 & 34,0 & \multirow{2}{*}{42} & \multirow{2}{*}{$<0,001$} \\
\hline & Sau 3 tháng & $7,8 \pm 7,5$ & 0 & 24 & & \\
\hline \multirow{2}{*}{ CEA (ng/ml) } & Ban đâu & $80,7 \pm 27,2$ & 1,4 & 497 & \multirow{2}{*}{31} & \multirow{2}{*}{0,003} \\
\hline & Sau 3 tháng & $36,7 \pm 19,1$ & 1,9 & 667 & & \\
\hline \multirow{2}{*}{$\begin{array}{c}\text { Cyfra 21-1 } \\
\text { (ng/ml) }\end{array}$} & Ban đầu & $5,2 \pm 1,0$ & 1,5 & 19,9 & \multirow{2}{*}{25} & \multirow{2}{*}{0,38} \\
\hline & Sau 3 tháng & $4,3 \pm 1,2$ & 0,9 & 29,9 & & \\
\hline
\end{tabular}

Nhận xét: Kích thước u phổi, u não, nồng độ chất chỉ điếm u CEA sau điều trị 3 tháng đều giảm so với trước điều trị, sự khác biệt có ý nghĩa thống kê với $\mathrm{p}<0,01$. Sự khác biệt về nồng độ Cyfra 21-1 trước và sau điêu trị không có ý nghĩa thống kê với $p>0,05$.

Bảng 3. Phân tích đa biến các yếu tố liên quan sống thêm toàn bộ

\begin{tabular}{|c|c|c|c|c|c|}
\hline & Yếu tố & $\begin{array}{c}\text { p đơn } \\
\text { biến }\end{array}$ & $\begin{array}{l}\text { p đa } \\
\text { biến }\end{array}$ & $\begin{array}{c}\text { Tỷ số } \\
\text { nguy cơ }\end{array}$ & $\begin{array}{c}\text { Khoảng tin } \\
\text { cậy 95\% }\end{array}$ \\
\hline & PS $(0-1,2)$ & 0,03 & 0,72 & 0,84 & $0,32-2,21$ \\
\hline & Giai đoạn T $(1-2,3-4)$ & 0,02 & 0,05 & 0,38 & $0,14-1,00$ \\
\hline \multirow{3}{*}{$\begin{array}{l}\text { Thuốc } \\
\text { đích }\end{array}$} & Erlotinib, Gefitinib & \multirow{3}{*}{0,01} & 0,11 & 2,46 & $0,81-7,45$ \\
\hline & Erlotinib, Afatinib & & 0,13 & 0,06 & $0,00-2,01$ \\
\hline & Gefitinib, Afatinib & & 0,91 & 1,14 & $0,13-10,22$ \\
\hline \multirow{3}{*}{$\begin{array}{l}\text { Điều trị } \\
\text { Bước } 2\end{array}$} & Không,TKI bước2 & & 0,004 & 5,42 & $1,73-16,97$ \\
\hline & Không, hóa chất & & 0,17 & 2,94 & $0,62-13,98$ \\
\hline & TKI bước 2, hóa chất & & 0,02 & 0,07 & $0,007-0,67$ \\
\hline & tri não lân 2 (không, có) & $\begin{array}{c}0,001 \\
0,03\end{array}$ & 0,22 & 0,37 & $0,08-1,83$ \\
\hline
\end{tabular}

Bảng 4. Mối liên quan giữ̛́a các tác dụng hay gặp và thuốc điều trị đích

\begin{tabular}{|c|c|c|c|c|c|c|c|c|}
\hline \multirow{2}{*}{\multicolumn{2}{|c|}{ Độc tính }} & \multicolumn{2}{|c|}{ Gefitinib } & \multicolumn{2}{|c|}{ Erlotinib } & \multicolumn{2}{|c|}{ Afatinib } & \multirow{3}{*}{$\begin{array}{c}\mathbf{p} \\
0,12\end{array}$} \\
\hline & & $\mathbf{n}$ & $\%$ & $\mathbf{N}$ & $\%$ & $\mathbf{n}$ & $\%$ & \\
\hline \multirow{2}{*}{ Ban da } & không & 14 & 26,4 & 8 & 15,1 & 3 & 5,7 & \\
\hline & Độ 1-2 & 9 & 17,0 & 17 & 32,1 & 2 & 3,8 & \multirow{3}{*}{0,046} \\
\hline \multirow{2}{*}{ Tiêu chảy } & không & 21 & 39,6 & 21 & 39,6 & 2 & 3,8 & \\
\hline & Độ 1-2 & 2 & 3,8 & 4 & 7,5 & 3 & 5,7 & \\
\hline Tăng men & không & 18 & 34,0 & 24 & 45,3 & 5 & 9,4 & \multirow{2}{*}{0,16} \\
\hline gan & Độ 1-2 & 5 & 9,4 & 1 & 1,9 & 0 & 0 & \\
\hline
\end{tabular}

Nhận xét: Tác dụng phụ hay gặp nhất là ban da $(52,8 \%)$, tiêu chảy $(16,9 \%)$, các độc tính huyết học, chức năng gan thận ít gặp, đều mức độ nhẹ và vừa. Tiêu chảy gặp nhiều hơn ở nhóm điêu trị bằng Afatinib $(60 \%)$ so với Erlotinib và Gefitinib, sự khác biệt có ý nghĩa thống kê với $p<0,05$. Ban da có xu hướng gặp nhiều hơn ở nhóm điêuu trị bằng Erlotinib (68\%), tăng không có ý nghĩa thống kê với $p>0,05$. Đa số $B N$ tuân thủ phác đồ, độc tính mức độ vừa làm $2 \mathrm{BN}$ phải tạm dừng thời gian ngắn (1 BN dùng Erlotinib do ban da độ 2, 1 BN dùng Gefitinib do tăng creatinin độ 2), 2 BN giảm liêu Afatinib do ban da và tiêu chảy độ 2 .

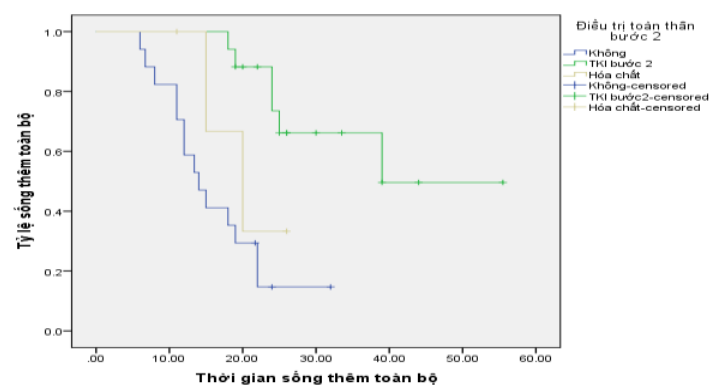

TKI bước 2(17) Hóa chất (4) Không (17); Trung vi STTB: 25,0 (khoảng tin cậy 95\%: 11,0-39,0);

TKI bước 2 - Hóa chất: $p=0,02 ;$ TKI bước 2 -

Không: $p=0,004$; Hóa chất - Không: $p=0,17$

Biểu đồ 5. Liên quan thời gian sống thêm toàn bộ theo điều trị toàn thân bước 2.

Nhẩn xét: Phân tích đa biến điêuu trị toàn thân bước 2 bằng thuốc TKI bước 2 (Afatinib, Osimertinib) so với hóa chất và không điêu trị là yếu tố tiên lượng độc lập ảnh hưởng đến thời gian sống thêm toàn bộ (với $p<0,05$ ).

\section{BÀN LUẬN}

Tỷ lệ cải thiện triệu chứng sau 3 tháng đạt $88,7 \%$, chủ yếu cải thiện triệu chứng hô hấp, thần kinh $(>85 \%)$, thấp nhất là đau xương $(73,7 \%)$. Kết quả của chúng tôi cao hơn đáng kể so với các nghiên cứu điều trị thuốc TKI đơn thuần cho UTPKTBN giai đoạn lan tràn $(77 \%)$ [5]. Mặc dù hóa chất có tỷ lệ đáp ứng khách quan thấp hơn thuốc TKI, nhưng kết quả của chúng tôi cao hơn ít so với kết quả nghiên cứu của Phạm Văn Thái điều trị BN UTPKTBN di căn não bằng phác đồ Paclitaxel-carboplatin kết hợp xạ phẫu dao gamma quay $(82,6 \%)[6]$. Điều này 
chứng tỏ cải thiện triệu chứng thần kinh chủ yếu nhờ vai trò của dao gamma quay điều trị tổn thương u não. Mặt khác, triệu chứng đau xương khó cải thiện hơn khi đã có tổn thương phá hủy xương, nghiên cứu của chúng tôi không loại trừ các BN di căn xương như nghiên cứu của Phạm Văn Thái. Đáp ứng khách quan trong nghiên cứu của chúng tôi là $69 \%$, chủ yếu đáp ứng một phần $(66,7 \%)$. Tỷ lệ đáp ứng chung của các thuốc TKI thế hệ 1,2 đối với UTPKTBN giai đoạn lan tràn là khoảng 56-70\% [7]. Phối hợp với vai trò của xạ phẫu u di căn não, tỷ lệ đáp ứng của phác đồ cũng được cải thiện hơn so với điều trị thuốc TKI đớn thuần. So với trước điều trị, kích thước u phổi, u di căn não, nồng độ CEA sau điều trị đều giảm có ý nghĩa thống kê, với $p<$ 0,01 . Marker CEA là một chất chỉ điểm tốt để theo dõi đáp ứng và dự báo tiến triển (bảng 2 ). Thời gian STBKTT đạt trung vị 14,0 tháng (KTC 95\%: 11,0-16,3 tháng), kêt quả này dài hơn so với điều trị TKI thế hệ 1,2 đơn thuần đối với UTPKTBN giai đoạn lan tràn, thời gian trung vị STBKTT được báo cáo khoảng 10,4-13,0 tháng [8]. Đáp ứng khách quan sau 3 tháng là yếu tố tiên lượng độc lập thời gian STBKTT. Đột biến Del 19 là tiên lượng thuận lợi kéo dài thời gian STBKTT khi điều trị bằng Erlotinib, trong nghiên cứu đột biến gen không ảnh hưởng đến thời gian STBKTT. Lý giải điều này, BN được điều trị với cả các thuốc Gefitinib, Afatinib, đột biến gen Del 19 không có lợi thế đáp ứng và STBKTT khi dùng các thuốc này. Trung vị thời gian STKTT tại não đạt 22,0 tháng (KTC 95\%: 18,2-25,8 tháng). Kết quả của chúng tôi tương tự nghiên cứu của Magnuson là 23,0 tháng (KTC 95\%: 18-28 tháng), dài hơn nghiên cứu của Seung- Hyeon Yang, Limin Chen lần lượt là 19,0 tháng và 14,7 tháng [9]. Xạ phẫu đảm bảo liều sinh học tại khối u di căn não phối hợp với thuốc TKI tiêu diệt các tổn thương u mức vi thể làm tăng khả năng triệt căn u di căn não, tiên lượng ở các $B N$ di căn não đơn độc sẽ tốt hơn rất nhiều. Phân tích đa biến, trung vị thời gian STTB ở nhóm có chỉ định điêu trị toàn thân $(n=38)$, điều trị thuốc đích bước 2 (Afatinib, Osimertinib) có trung vị STTB dài hơn có ý nghĩa thống kê so với điều trị hóa chất và không điêu trị lần lượt là 39,0 tháng, 20,0 tháng, 14,0 tháng, với $p<0,05$. Nghiên cứu của Magnuson, trung vị thời gian STTB đạt 45 tháng dài hơn của chúng tôi. Lý giải cho điều này, nghiên cứu của chúng tôi thời gian theo dõi còn ngắn, số sự kiện tiến triển chưa quan sát đầy đủ, tỷ lệ $\mathrm{BN}$ điều trị bằng Erlotinib chỉ khoảng $50 \%$, tỷ lệ BN điều trị bước 2 chỉ đạt khoảng 1/2 (21/38BN). Trong khi đó nghiên cứu của Magnuson các quan sát đã hoàn thành, $78 \%$ BN đã tiến triển và đều được điều trị bước 2 bằng các phác đồ toàn thân cá thể hóa phù hợp cho từng $\mathrm{BN}$ như thuốc TKI bước 2, hóa chất. Độc tính của phác đồ hay gặp nhất là ban da, tiều chảy, các độc tính huyết học, chức năng gan thận ít gặp, đều mức độ nhe đến vừa. Điều trị bằng Afatinib cho tỷ lệ tiêu chảy cao hơn có ý nghĩa thống kê so với điều trị bằng Gefitinib và Erlotinib, $p<0,05$. Trong khi đó, tăng men gan có xu hướng gặp nhiều hơn ở nhóm điều trị bằng Gefitinib, ban da có xu hướng gặp nhiêu ở nhóm điều trị bằng Erlotinib, sự khác biệt không có ý nghĩa thống kê, với $p>0,05$. Các phân tích gộp trên số lượng lớn $\mathrm{BN}$ cho thấy điều trị bằng Afatinib, Erlotinib có nguy cơ bị phát ban nhiề hơn Gefitinib, tiêu chảy gặp nhiều ở nhóm điều trị bằng Afatinib hơn, tăng men gan lại gặp nhiều ở nhóm điều trị bằng Gefitinib hơn, sự khác biệt có ý nghĩa thống kê với $p<0,01$. Nghiên cứu của chúng tôi phân nhóm điều trị các thuốc đích khác nhau có số lượng còn ít, nên sự khác biệt về độc tính giữa các nhóm còn chưa rõ.

\section{KẾT LUẬN}

- Tỷ lệ cải thiện triệu chứng chủ quan cao $(88,7 \%)$. Tỷ lệ đáp úng khách quan là $69,0 \%$ chủ yếu là đáp ứng 1 phần $(66,7 \%)$, không có sự khác biệt có ý nghĩa thống kê giữa các thuốc đích với $p>0,05$. So sánh trước và sau điều trị 3 tháng, kích thước u phổi, u di căn não, nồng độ CEA đều giảm có ý nghĩa thống kê với $p<0,001$.

- Thời gian sống thêm được tính theo phương pháp Kaplan-Meyer. Thời gian sống thêm bệnh không tiến triển đạt trung vị 14,0 tháng (khoảng tin cậy 95\%: 11,6-16,4 tháng). Đáp ứng khách quan là yếu tố tiên lượng thời gian sống thêm bệnh không tiến triển với $p<0,01$. Trung vị thời gian sống thêm bệnh không tiến triển tại não đạt 22,0 tháng (khoảng tin cậy $95 \%$ : 18,2-25,8 tháng). Điều trị toàn thân bằng Erlotinib cho thời gian sống thêm bệnh không tiến triển tại não dài hơn Gefitinib và Afatinib khi phân tích đa biến với $p<0,05$. Trung vị thời gian sống thêm toàn bộ đạt 25,0 tháng (khoảng tin cậy 95\%: 11,0-39,0 tháng), tỷ lệ sống 1 năm đạt $85,7 \%$, 2 năm đạt $52,0 \%$. Phân tích đa biến, điều trị toàn thân bước 2 bằng thuốc đích bước 2 cho trung vị thời gian sống thêm toàn bộ dài hơn hóa chất và không điêu trị lần lượt là 39 tháng, 20 tháng, 14 tháng, sự khác biệt có ý nghĩa thống kê với $p<0,05$.

- Tác dụng phụ hay gặp của phác đồ là ban da $(52,8 \%)$, tiêu chảy $(16,9 \%)$, thay đổi móng 
(15\%), tăng men gan (11,3\%), đều mức độ nhe đến vừa. Không có biến chứng giãn não thất, hoại tử mô não lành sau xạ phẩu. Tiêu chảy gặp nhiều ở nhóm điều trị bằng Afatinib hơn Erlotinib và Gefitinib, sư khác biêt có ý nghĩa thống kê với $\mathrm{p}<0,05$. Đa số bệnh nhân tuân thủ phác đồ, độc tính mức độ vừa làm 2 bệnh nhân phải tạm dừng thời gian ngắn, 2 bệnh nhân giảm liều.

\section{TÀI LIẸU THAM KHẢO}

1. Sung $H$, Ferlay J, Siegel $R$ L (2021). "Global Cancer Statistics 2020: GLOBOCAN Estimates of Incidence and Mortality Worldwide for 36 Cancers in 185 Countries". 71 (3), 209-249.

2. Davis F G, Dolecek T A, McCarthy B J, et al (2012). "Toward determining the lifetime occurrence of metastatic brain tumors estimated from 2007 United States cancer incidence data". Neuro Oncol, 14 (9), 1171-1177.

3. Mai Trong Khoa (2020). Hướng dẫn chẩn đoán và điều trị một số bệnh lý ung bướu, Nhà xuất bản Y học,

4. Mok $T S, W i \quad Y L$, Thongprasert $S$, et al (2009). "Gefitinib or carboplatin-paclitaxel in pulmonary adenocarcinoma". N Engl J Med, 361 (10), 947-957.

5. Lê Thu Hà (2017). Đánh giá hiệu quả thuốc Erlotinib trong điêu trị ung thư phổi biểu mô tuyến giai đoạn muộn, Luận án Tiến sỹ y học, Trương Đại học y Hà Nối.

6. Pham Văn Thái (2014). Nghiên cứu điều tri ung thư phổi không tế bào nhỏ di căn não bằng hoá xạ trị, Luận án Tiến sỹ y học, Trường Đại học y Hà Nôii.

7. Park K, Tan E H, O'Byrne $K$, et al (2016). "Afatinib versus gefitinib as first-line treatment of patients with EGFR mutation-positive non-smallcell lung cancer (LUX-Lung 7): a phase 2B, openlabel, randomised controlled trial". Lancet Oncol, 17 (5), 577-589.

8. Nan $X$, Xie C, Yu $X$, et al (2017). "EGFR TKI as first-line treatment for patients with advanced EGFR mutation-positive non-small-cell lung cancer". Oncotarget, 8 (43), 75712-75726.

9. Yang $\mathbf{S} \mathbf{H}, \mathbf{K i m} \mathbf{H} \mathbf{Y}$ (2020). "The Effect of Epidermal Growth Factor Receptor Mutation on Intracranial Progression-Free Survival of Non-Small Cell Lung Cancer Patients with Brain Metastasis Underwent Gamma Knife Radiosurgery". 8 (2), 103-108.

\section{THIẾT LÂP KHOẢNG NỒNG Độ CỦA SÁU THÔNG Số THƯỜNG QUY AST, ALT, CHOLESTEROL, TRIGLYCERIDE, GLUCOSE VÀ PROTEIN TRONG CHẾ TẠO MẪU NGOẠI KIỂM HÓA SINH}

Trần Hưuu Tâm*, Trương Quân Thụy*, Vũ Đình Dũng*, Nguyễn Thị Hồng Phương*, Nguyễn Thị Ngọc Vân*, Vũ Thị Như Oanh*, Nguyễn Đàm Châu Bảo*

\section{TÓM TẮT}

Xét nghiệm hóa sinh là một trong những chỉ định cận lâm sàng thường quy nhất tại các đơn vị y tế, các xét nghiệm này là căn cứ góp phần giúp các nhà lâm sàng đựa ra quyết định quan trọng cho công tác điều trị, chẩn đoán sớm và dự phòng bệnh, nghiên cứu khoa học trong y học,... Một trong nhứng công tác nhẳm đảm bảo đô tin cây và chất lương của xét nghiệm hóa sinh là ngoại kiểm tra chất lượng xét nghiềm $[1,2,3]$. Để chế tao mẫu ngoai kiểm cần có khoảng nồng độ cao, thấp, bình thường của các thông số đế sử dung trong quá trình pha chế mẫu. Sáu thông số hóa sinh thường quy được khảo sát gồm protein glucose, cholesterol, triglyceride, AST, ALT. Kết quả thu được khoảng nồng độ cao của glucose là $9,50-24,00 \mathrm{mmol} / \mathrm{L}$, protein là $95-115 \mathrm{~g} / \mathrm{L}$, cholesterol là $6,20-9,00 \mathrm{mmol} / \mathrm{L}$, triglyceride là 2,70 $9,50 \mathrm{mmol} / \mathrm{L}$, AST là 95 - $350 \mathrm{U} / \mathrm{L}$, ALT là $95-300 \mathrm{U} / \mathrm{L}$;

*Trung tâm Kiểm chuẩn Xét nghiệm TP.HCM

Chịu trách nhiệm chính: Trần Hữu Tâm

Email: trhuutam@yahoo.com

Ngày nhận bài: 23.6.2021

Ngày phản biện khoa học: 20.8 .2021

Ngày duyệt bài: 26.8.2021 khoảng nồng đô thâp của glucose là 2,49 - 3,90 $\mathrm{mmol} / \mathrm{L}$, protein là $10-40 \mathrm{~g} / \mathrm{L}$, cholesterol là $2,50-$ $3,70 \mathrm{mmol} / \mathrm{L}$, triglyceride là $0,20-1,00 \mathrm{mmol} / \mathrm{L}$, AST là 7 - $24 \mathrm{U} / \mathrm{L}$, $A L T$ là 7 - $24 \mathrm{U} / \mathrm{L}$; khoảng nồng độ bình thường của glucose là $4,00-9,00 \mathrm{mmol} / \mathrm{L}$, protein là $45-90 \mathrm{~g} / \mathrm{L}$, cholesterol là $3,80-6,10 \mathrm{mmol} / \mathrm{L}$, triglyceride là $1,10-2,60 \mathrm{mmol} / \mathrm{L}, A S T$ là $25-94 \mathrm{U} / \mathrm{L}$, ALT là 25-94 U/L.

Tư khóa: ngoại kiểm tra, nội kiểm tra.

\section{SUMMARY}

\section{CONCENTRATION RANGES OF SIX ROUTINE \\ PARAMETERS AST, ALT, CHOLESTEROL, TRIGLYCERIDE, GLUCOSE AND PROTEIN FOR CREATING CLINICAL CHEMISTRY EXTERNAL QUALITY ASSESSMENT SAMPLES}

Clinical chemistry test is one of the most routine indications in medical units, it is basic in helping clinicians make important decisions for treatment, early diagnosis and disease prevention, scientific research in medicine,... One of the tasks to ensure the reliability and quality of biochemical tests is external quality assessment $[1,2,3]$. To make an external quality assessment sample, the level of high, low and normal concentration range of the parameters is required for using in the sample preparation process. Six routine clinical chemistry parameters were 